University at Buffalo School of Law

Digital Commons @ University at Buffalo School of Law

\title{
Trends in Private Land Conservation: Increasing Complexity, Shifting Conservation Purposes and Allowable Private Land Uses
}

Jessica Owley

University of Miami School of Law

Adena R. Rissman

University of Wisconsin-Madison

Follow this and additional works at: https://digitalcommons.law.buffalo.edu/journal_articles

Part of the Environmental Law Commons, and the Land Use Law Commons

\section{Recommended Citation}

Jessica Owley \& Adena R. Rissman, Trends in Private Land Conservation: Increasing Complexity, Shifting Conservation Purposes and Allowable Private Land Uses, 51 Land Use Pol'y 76 (2016).

Available at: https://digitalcommons.law.buffalo.edu/journal_articles/185

(C) 2015 Elsevier Ltd. This manuscript version is made available under the CC-BY-NC-ND 4.0 license http://creativecommons.org/licenses/by-nc-nd/4.0/. Version of record available at: https://doi.org/10.1016/ j.landusepol.2015.10.026.

\section{c) (1) () $९$}

This work is licensed under a Creative Commons Attribution-NonCommercial-NoDerivatives 4.0 International License.

This Article is brought to you for free and open access by the Faculty Scholarship at Digital Commons @ University at Buffalo School of Law. It has been accepted for inclusion in Journal Articles by an authorized administrator of Digital Commons @ University at Buffalo School of Law. For more information, please contact lawscholar@buffalo.edu. 
1 Trends in Private Land Conservation: Increasing Complexity, Shifting Definitions of

2 Conservation and Allowable Private Land Use

3 Jessica Owley [Corresponding Author]

4 Associate Professor

5 SUNY Buffalo Law School

6722 O’Brian Hall

7 Buffalo, NY 14260

8 United States

9 E-mail: jol@buffalo.edu

10 Adena R. Rissmann

11 Associate Professor

12 University of Wisconsin

131630 Linden Drive, Room 111

14 Madison, WI 53706

15 United States

16 E-mail: arrissman@wisc.edu

18 Abstract: The terrain of private-land conservation dealmaking is shifting. As the number of acres

19 of private land protected for conservation increases, our understanding of what it means for a

20 property to be "conserved" is shifting. We examined 269 conservation easements and conducted

2173 interviews with land conservation organizations to investigate changes in private-land

22 conservation in the United States. We hypothesized that since 2000, conservation easements

23 have become more complex but less restrictive. Our analysis reveals shifts in what it means for

24 private land to be "conserved." We found that conservation easements have indeed become more

25 complex, with more purposes and terms after 2000 compared to conservation easements

26 recorded before 2000. However, changes in restrictiveness of conservation easements varied by

27 land use. Mining and waste dumping were less likely to be allowed after 2000, but new 
28 residences and structures were twice as likely to be allowed. We found a shift toward allowing

29 some bounded timber harvest and grazing, and a decline in terms that entirely allow or prohibit

30 these working land uses. Interviews revealed staff perceptions of reasons for these changes. Our

31 analysis suggests that "used" landscapes are increasingly important for conservation but that

32 conserving these properties stretches the limits of simple, perpetual policy tools and requires

33 increasingly complex and contingent agreements.

34 Highlights:

35 - Conservation easement deeds are more complex with more complicated land use terms

36 - Increased conservation on working land alters the private conservation landscape

37 - Using partial-property tools for private land conservation is limited

38 Keywords: Conservation easements, land trusts, nonprofit organizations, private-land

39 conservation, property rights

40 Acknowledgements/Funding Sources: This project was funded in part by grants from the

41 Resources Legacy Foundation and the Baldy Center for Law \& Social Policy. The funders

42 played no role in study design; data collection, analysis and interpretation; choice of publication

43 venue; or the writing of this Article.

44 
45 Trends in Private Land Conservation: Increasing Complexity, Shifting Definitions of

46 Conservation and Allowable Private Land Use

$48 \quad 1 . \quad$ INTRODUCTION

49 Land conservation can prevent development and enhance environmental management and

50 recreation. Conservation easements are part of the global trend toward decentralized

51 environmental governance in which nonprofit and government entities negotiate standards and

52 enforce rules (Owley, 2013). Internationally, public agencies and nonprofit organizations have

53 sought ways to augment land protection and are increasingly relying on conservation easements

54 (CEs). As CEs become increasingly important for land conservation, it is helpful to understand

55 how the tool is evolving (Merenlender et al., 2004). Since they are perpetual restrictions on land

56 based on today's understanding and preferences, CEs tend to remain fixed once established with

57 subsequent transactions reflecting organizational learning and changing conservation contexts

58 (Rissman, 2011). Organizations and landowners are learning from experience and responding to

59 changing institutional contexts for conservation, so CEs established in the 1980s and 1990s may

60 be substantially different from those of more recent decades.

61 We examined 269 conservation easements from six U.S. states to investigate differences

62 between older and more recent CEs and conducted 73 interviews with staff of organizations

63 holding these CEs. The CE and interview data present a compelling story of change within

64 private-land conservation. Scholars and practitioners have noted increasing sophistication of CEs

65 (Boyd et al., 1999). Yet, the trends and contours of these changes have not been examined

66 systemically. Understanding how CEs are changing provides important information to land

67 conservation stakeholders considering how to conserve land. 
69 CEs are nonpossessory rights in land with a conservation purpose. The holder of a CE is a 70 government agency, nonprofit land trust, or Native American tribe with a nonpossessory right in 71 another person or entity's real property. Such rights are generally negative, prohibiting the

72 landowner from doing something she would have otherwise been able to do. CEs can also 73 contain affirmative rights, giving the CE holder the right to do something the landowner could

74 have otherwise prohibited. Whether negative or affirmative, the goal of the restriction is to yield 75 a conservation benefit (NCCUSL, 2007). CEs vary widely in purposes, restrictions, and the size 76 and landscape context of conserved properties. Common examples of CE terms include

77 prohibitions on development, limitations on activities in wetlands, and rules regarding forestry 78 and agricultural practices.

The CE tool has evolved significantly. Historically, courts did not approve of CEs,

80 disfavoring long-term restrictions on land that made transfers and negotiations regarding land

81 uses more cumbersome. Conservationists grew dissatisfied with the limitations of public land

82 conservation and land-use regulation and began to look for additional mechanisms to protect

83 environmental amenities (Owley, 2006). CEs appeared a logical outgrowth of traditional

84 property agreements like easements and real covenants that restrict a landowner's behavior on

85 her own land or permit a right holder to do something on the land (like trespassing) that the

86 landowner would otherwise have been able to prohibit. CEs needed new legal foundations due to

87 inherent legal conflicts with traditional real estate mechanisms (that limited permissible holders

88 and purposes of servitudes) and the desires of conservationists (Cheever, 1996). Therefore,

89 beginning in earnest in the 1970s and increasing after a 1981 Uniform Act, U.S. states enacted

90 CE statutes validating the use of such agreements and creating foundations for their enforcement. 
91 The CE deduction was added to the U.S. federal tax code in 1980, enabling a charitable tax

92 deduction for donated CEs and estate tax benefits. All fifty states, Washington D.C., Puerto Rico,

93 and the Virgin Islands now have CE statutes. Other nations have been following this model, and

94 we now see CE-like structures in the United Kingdom, Australia, Canada, Kenya, Costa Rica and

95 Mexico (Di Leva, 2002; Jacobs, 2014; Korngold, 2010; Rissman et al., 2014). There are also

96 proposals for development elsewhere, including Papua New Guinea and Chile (Root-Bernstein et

97 al., 2013; Stolton et al., 2014; Telesetsky, 2001).

98 The growth in CEs in the U.S. has been driven by the growth of the land trust movement and

99 the infusion of public funding from ballot initiatives and the U.S. Farm Bill. The number of land

100 trusts has grown at an incredible rate. In 1950, there were only 53 land trusts, and in 2011 there

101 were over 1,700 (McLaughlin, 2004). The 2010 Land Trust Alliance's Census tallied the total

102 hectares of CEs held by land trusts at over 19 million (Chang, 2011). In 2000, there were only

1039.3 million hectares held by state, local, and national land trusts. This number does not include

104 the millions of additional hectares held by government agencies.

105 The land trust movement and the use of CEs matured between the 1980s and 2010s. The

106 Land Trust Alliance first published The Conservation Easement Handbook in 1988 and the

107 Standards and Practices Guidebook in 1993. Farm Bill funding became available for land-trust-

108 held CEs in 2002 (Alliance, 2013). By the early 2000s, CEs were subject to heightened

109 academic, media, and governmental scrutiny. Senate Finance Committee and IRS investigations

110 began in 2003, resulting in hundreds of CE audits. The Land Trust Accreditation Commission

111 was created in 2006 to set national organizational standards.

112 We expected to see two trends in CE terms: increasing complexity and declining

113 restrictiveness of private land use. Our research group has experience working with CEs as 
114 attorneys, academic researchers, and board members of land trusts. This experience suggests that

115 CEs are getting longer and more complicated. At the same time, however, CEs appear to be

116 allowing more development and landowner uses of the conserved property. We conducted a

117 survey of CE documents and interviews with $\mathrm{CE}$ holders to test our hypotheses and quantify

118 these trends, comparing CEs created before and after 2000.

$119 \quad$ Hypothesis 1: Conservation easements have increased in complexity.

120 We expected to find that CEs increased in complexity, with newer CEs including more

121 purposes and terms. Contract theory, diffusion of innovation, and organizational learning suggest

122 an increase in complexity over time (Argyres et al., 2007; Gray, 1973; Vanneste and Puranam,

123 2008). CEs evolved in conjunction with changes in state and federal law, funder requirements,

124 and increased public scrutiny. As land trusts and government agencies mature and CE use

125 increases, holders are more likely to be repeat participants. With this experience and the growth

126 in the number of attorneys working with CEs, we expect organizations to anticipate more

127 potentialities and negotiate for more terms, seeking to maximize the likelihood of achieving their

128 conservation goals. We also expect that donated CEs might be less complex than purchased or

129 partially-purchased CEs (Rissman, 2010). CEs are also more likely to be part of mitigation for

130 development or other habitat destruction in which the expectation for defined rules and duties is

131 higher (Owley, 2011). Larger properties may also require greater complexity in CE terms.

132 An increase in complexity of conservation easements would be consistent with trends seen in 133 other types of contractual documents. Attorneys often seek to improve contract completeness by 134 adding contingency planning or by increasing contract details (Argyres et al., 2007) (Crocker and 135 Reynolds, 1993). As parties to contracts learn about potential outcomes through personal 
136 experience, court cases, and news reports, they add contract language regarding such events.

137 Though characterized as deed restrictions, CEs are similar to contracts, are often referred to as 138 contracts (Tegene et al., 1999), and courts use contract rules when interpreting them (Haines, 139 2012).

140 Innovative terms may also have diffused through conservation organizations. Diffusion of 141 innovation occurs where there is "communication of a new idea in a social system over time" 142 (Gray, 1973). Increased levels of interaction though social media likely magnify this effect. For 143 example, increased use of model CEs, publications like the Conservation Easement Handbook or 144 the Land Trust Alliance's Standards and Practices, or discussions on the Land Trust Alliance 145 listservs enable drafters to easily adopt terms and techniques used by others. It is also possible 146 that there is a bandwagon effect (Asch, 1955) for CE terms. That is, the probability of any holder 147 adopting a particular term increases with the proportion of holders who has already done so 148 (Colman, 2012).

149 Organizational learning theory supports the hypothesis of increasing complexity.

150 Organizational learning is a change in an organization's practices based on experience (Argote, 151 2013). As land trusts enter into more conservation easements, staff members change and improve 152 their conservation easements based on their earlier transactions and in reaction to conflicts that 153 have arisen with landowners. Repeated interactions enable drafters to capture more 154 contingencies. Changes are more frequently driven by actual experiences rather than increased 155 ability to predict potential future occurrences (Mayer and Argyres, 2004). It is impossible to 156 foresee all contingencies, and staff identify important terms that were left out of prior CEs. For 157 example, if land trusts have problems with landowners dumping trash, they are likely to add 158 provisions on waste dumping to future CEs. Incorporating new CE terms guards against 
159 organizational forgetting and may leave terms in subsequent CEs long after individual staff

160 members have forgotten why the terms first appeared (Argote, 1999).

161 1.3. Hypothesis 2: Conservation easements have decreased in restrictiveness.

162 While CE documents may become increasingly complex, the restrictions on landowners may

163 be lessening. ${ }^{1}$ We hypothesized that recent CEs would allow landowners to exercise more land-

164 use rights for a few reasons. The earliest CEs preserved key landmarks or were viewed as

165 "forever wild" CEs that did not allow substantial use or development of those properties (Jacobs,

166 2014). CEs are now used in more contexts and on larger properties. They may be more likely to

167 be part of a large-scale suburban development, in urban areas, or on a golf course. To attract new

168 landowners and enable a growing conservation land base, CEs may also increasingly encumber

169 residential properties or large working lands with active farming, grazing, and timber harvesting.

170 In these cases, landowners typically retain rights to conduct activities on the lands. Changes in

171 funding and conservation organization priorities could also contribute to decreased restrictions

172 on land use. One trend that may run counter to this hypothesis is that donated CEs may contain

173 fewer restrictions than purchased or other CEs, since landowners typically receive less financial

174 incentive for a donated CE. Purchased CEs have increased with funding from the Farm Bill and

175 voter-approved bond initiatives.

$176 \quad$ 2. METHODS

177 We examined 269 CEs from six states in the U.S. (California, Colorado, Indiana, New York,

178 South Carolina, and Wisconsin). We collected the CEs through a distributed graduate seminar

\footnotetext{
${ }^{1}$ In fact, the most restrictive development term could be extremely short: "No Development Anywhere on the Property." When the landowners have more rights, the provisions get longer, detailing where development may occur, what form it will take, and what approval process is required.
} 
179 conducted among six universities in Spring 2011 (Ref Redacted). To include a wide range of

180 land conservation organizations and CEs, we selected 63 land trusts and governmental holders

181 from 28 regions across the six states. We then acquired four CEs from each organization: the

182 oldest and newest CEs, a middle CE from the median year between the oldest and newest CE,

183 and the largest CE (by area) held by the organization in the study region. If the largest CE was

184 also the oldest, middle, or newest, the second largest CE was selected. We selected these CEs to

185 maximize the variation in terms within each organization.

186 We coded the CEs by categorizing their purposes, land-use terms, and procedural terms. To

187 analyze how CEs have changed, we divided the CEs into two groups: those recorded before 2000

188 ("before 2000" n=76) and those recorded from 2000-2011 ("after 2000" n=193). We split the

189 dataset at 2000 because the use of CEs increased dramatically by 2000. By that date,

190 conservation organizations had access to a variety of CE drafting resources including books,

191 conferences, and reports. Additionally, in the early 2000s funding for CEs grew with federal

192 programs like the Farm Bill and local bond initiatives. By the early 2000s, CEs were subject to

193 heightened academic, media, and governmental scrutiny. With some experience under their belts,

194 drafters were incorporating lessons from earlier projects.

195 Our sample had similar dominant land cover, state, and type of holder (government or NGO), 196 or type of landowner (private, NGO, or government) before and after 2000 (Appendix Table 1).

197 Our sample had fewer small properties and donated CEs after 2000. For this reason, we control

198 for property size and whether the CE was donated in all multivariate analyses.

199 To test our first hypothesis of an increase in complexity, we first examined whether the number 200 of purposes was higher after 2000 by conducting a multiple linear regression (all analyses in IBM 201 SPSS v.22) of the number of purposes in each CE with independent variables year (before or after 

2000), property size (larger or smaller than 500 acres), and whether the CE was donated (yes/no),

203 and a size*year interaction term. The size*year interaction term was not significant, so it was 204 removed from the final model. We conducted chi-squared analyses of whether specific purpose 205 clauses and types of purposes were more or less common after 2000.

206 Second, we tracked the presence of 17 land-use and 5 procedural CE terms. We developed this 207 list of provisions based on the Land Trust Alliance's Conservation Easement Handbook and our 208 previous experience with CEs. We created a land use complexity metric that summed the number 209 of land uses that each CE mentioned (including provisions to restrict or permit the land use), out 210 of 17 land use categories. We hypothesized that CEs after 2000 would mention more land uses 211 than CEs before 2000, which we tested with the nonparametric Mann-Whitney U test. We used 212 the nonparametric test here because the complexity metric sums many diverse types of easement 213 terms. We tested change in presence of five procedural terms (termination, condemnation, Acts of 214 God, amendment, dispute resolution) before and after 2000 with chi-squared analysis.

215 Our second hypothesis considered whether later CEs are less likely to restrict landowners' 216 private land uses. When examining CE terms to test this hypothesis, we looked for both the 217 presence of terms and their meaning. For example, instead of just asking whether the CE had a 218 term about invasive species, we examined what that term said and what level of control the CE 219 purported to exert over landowner action. We examined whether CEs became more restrictive 220 through chi-squared analysis of land-use restrictions.

221 We compared development terms in CEs before and after 2000 with multinomial logistic 222 regression $(n=269)$, controlling for property size, working land purpose (including forestry, 223 grazing, or agriculture), and whether the CE was donated. Development restrictions were divided 224 into three categories: no new development; one residence, agricultural building, cabins, or other 
structures; and two or more new residences allowed. The final model regressed development terms

226 with year (before or after 2000), size of property (smaller or larger than 500 acres), and whether

227 the CE included a working land purpose. We initially included a year*size interaction term and

228 whether the CE was donated, but these variables were not significant and were removed from the

229 final model to minimize AIC.

230 We also developed multinomial logistic regressions to examine whether timber harvest

231 grazing terms were more or less restrictive after 2000. We classified the dominant land cover of

232 each CE based on GIS maps, Google Earth, and document descriptions. We examined harvest

233 terms on forested CEs (126) and grazing terms on grass/shrub CEs (108). Properties with a

234 dominant land cover of wetland (31) or other (4) were excluded. For forest properties, we

235 examined whether CE terms allowed any timber harvest, some timber harvest (with restrictions

236 in the CE or an associated management plan), or no timber harvest were more or less common

237 after 2000, controlling for property size, working land purpose, and whether the CE was donated

238 (n=126). Property size, a size* year interaction term, and donated were not significant and were

239 removed from the final model due to selection to minimize AIC. For grass/shrub properties, we

240 examined whether CE terms that allowed any grazing, some grazing (with restrictions in the CE

241 or an associated management plan), or no grazing were more or less common after 2000,

242 controlling for property size, working land purpose, and whether the CE was donated $(n=108)$. A

243 size*year interaction term and donated were included in the preliminary grazing terms model but

244 were removed because they were not significant and removing them minimized AIC.

245 We conducted 73 structured interviews based on a standard questionnaire with staff from 63

246 land trusts or government agencies. These structured interviews were conducted by phone $(n=49)$,

247 in person $(n=22)$, or through written email correspondence when this was preferred by 
248 organizational staff $(\mathrm{n}=2)$. We asked staff involved with CEs to describe the organization's

249 approach to drafting CE language and how that approach has changed over time. We inductively

250 coded open-ended questions (Boyatzis, 1998) and identified sixteen recurring themes.

$2513 . \quad$ RESULTS

252 3.1. Complexity

253 Multiple analyses support the hypothesis of an increase in CE complexity. First, we found an 254 increase in the number of CE purposes (Fig. 1). CEs since 2000 had an average of 7.8 purposes, 255 compared to 5.4 purposes before 2000. A multiple linear regression found that CEs after 2000 had 256 more purposes (standardized $\beta=0.392, \mathrm{t}=6.247, \mathrm{p}<0.001$ ) and larger CEs over 500 acres had more 257 purposes (standardized $\beta=0.195, \mathrm{t}=3.482, \mathrm{p}=0.001$ ), while donated CEs (standardized $\beta=-0.195$, $258 \mathrm{t}=-3.345, \mathrm{p}=0.001$ ) had fewer purposes (full model adjusted $\mathrm{r}^{2}=0.184, \mathrm{~F}=21.184, \mathrm{p}<0.001$ ). CEs 259 created after 2000 were more likely to have specific purposes with lists of specific conservation 260 values, species and natural communities, and goals to protect working land uses like forestry, 261 grazing, or farming (Appendix Table 2). 
263 Figure 1. Conservation easements created after 2000 have more purposes than those created before 2642000.

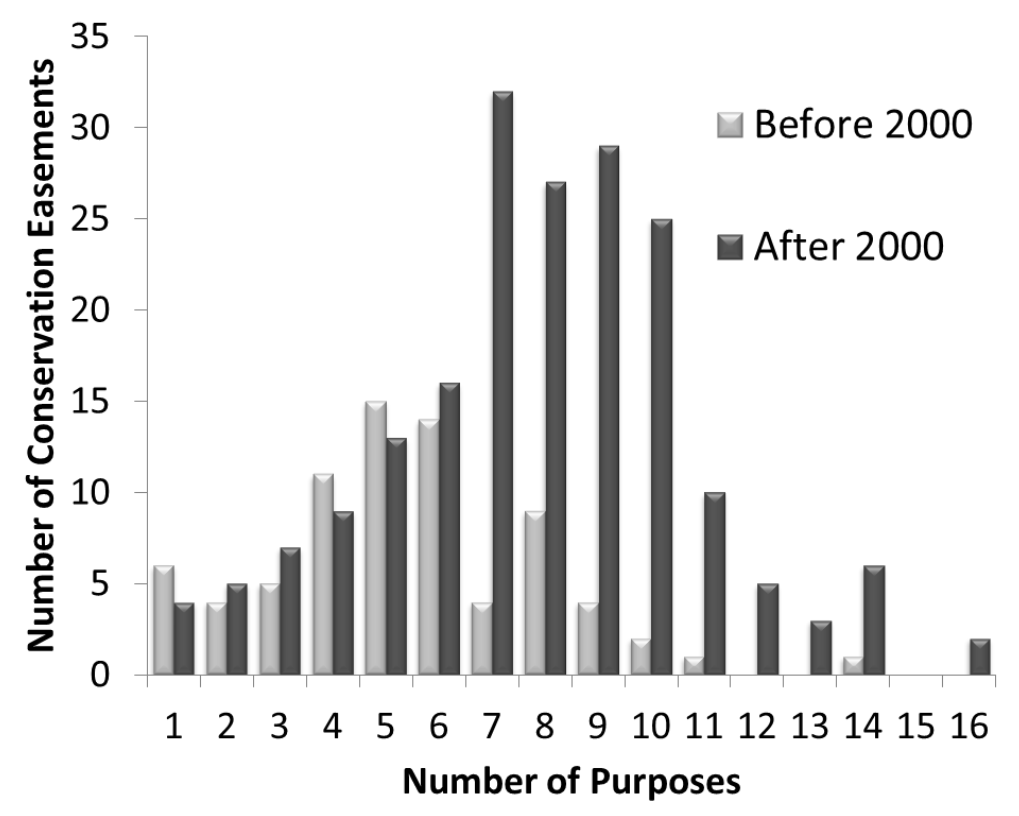

265

266 The complexity of land-use provisions increased (Fig. 2). CEs after 2000 had more terms 267 regarding land-use restrictions, with a mean of 12.5 land-use terms after 2000, compared with 10.2 268 terms before 2000 (Mann-Whitney U Test, $\mathrm{n}=269, z=-5.49, \mathrm{p}<0.001$, two-sided). The land-use 269 complexity metric summed the land uses in Table 1. 
Figure 2. The complexity of land-use terms in conservation easements is higher after 2000.

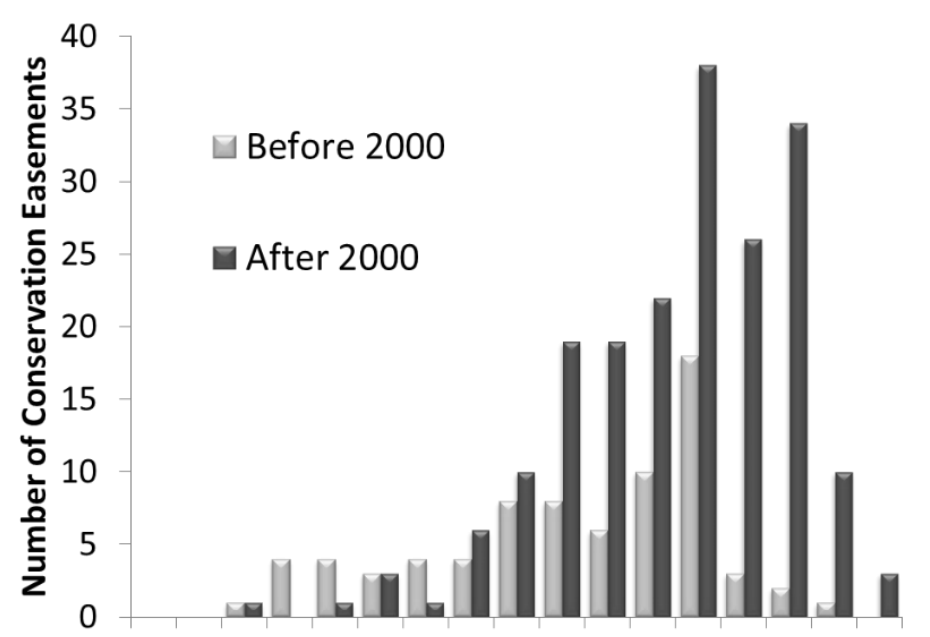

$\begin{array}{lllllllllll}1 & 2 & 3 & 4 & 5 & 6 & 7 & 8 & 9 & 1011 & 121314151617\end{array}$ Land Use Complexity Metric

272 Table 1. Seventeen land-use terms included in the land-use complexity metric.

\begin{tabular}{|c|c|c|c|}
\hline Land-Use Terms & $\begin{array}{l}\text { Percentage } \\
\text { of CEs } \\
\text { Before } 2000 \\
(n=76) \\
\text { containing } \\
\text { the term }\end{array}$ & $\begin{array}{l}\text { Percentage } \\
\text { of CEs After } \\
2000(n=193) \\
\text { containing } \\
\text { the term }\end{array}$ & $\begin{array}{l}\text { Increase } \\
\text { in } \\
\text { percentage }\end{array}$ \\
\hline New Structures, Buildings, or Roads Mentioned & $94.7 \%$ & $99.0 \%$ & $4.3 \%$ \\
\hline Alteration of Land Mentioned & $84.2 \%$ & $84.5 \%$ & $0.3 \%$ \\
\hline Waste Dumping Mentioned & $81.6 \%$ & $94.3 \%$ & $12.7 \%$ \\
\hline Public Access Mentioned & $81.6 \%$ & $91.7 \%$ & $10.1 \%$ \\
\hline Timber Harvest Mentioned & $76.3 \%$ & $91.2 \%$ & $14.9 \%$ \\
\hline Alteration of Water Courses Mentioned & $72.4 \%$ & $82.9 \%$ & $10.5 \%$ \\
\hline Commercial Recreation Mentioned & $71.1 \%$ & $82.8 \%$ & $11.7 \%$ \\
\hline Mining Mentioned & $69.0 \%$ & $91.9 \%$ & $22.9 \%$ \\
\hline Subdivision of the Property Mentioned & $64.5 \%$ & $85.0 \%$ & $20.5 \%$ \\
\hline Farming Mentioned & $64.5 \%$ & $83.4 \%$ & $18.9 \%$ \\
\hline Livestock Grazing Mentioned & $56.6 \%$ & $76.7 \%$ & $20.1 \%$ \\
\hline Invasive Species Mentioned & $56.6 \%$ & $68.4 \%$ & $11.8 \%$ \\
\hline Wildlife Mentioned & $39.2 \%$ & $56.5 \%$ & $17.3 \%$ \\
\hline Water Rights Mentioned & $36.6 \%$ & $53.2 \%$ & $16.6 \%$ \\
\hline Management Plan Mentioned & $31.0 \%$ & $56.8 \%$ & $25.8 \%$ \\
\hline Prescribed Fire Mentioned & $21.1 \%$ & $34.2 \%$ & $13.1 \%$ \\
\hline Climate Change Mentioned & $1.3 \%$ & $3.6 \%$ & $2.3 \%$ \\
\hline
\end{tabular}


274 (Table 2). Termination and condemnation provisions, which are generally common, did not change

275 in frequency.

276 Table 2. Percent of CEs with each procedural clause before and after 2000.

277

\begin{tabular}{|l|r|r|r|c|}
\hline \multicolumn{1}{|c|}{ Procedural Terms } & \multicolumn{1}{c|}{$\boldsymbol{\chi}^{\mathbf{2}}$} & \multicolumn{1}{c|}{$\begin{array}{l}\text { P- } \\
\text { value }\end{array}$} & $\begin{array}{l}\text { Before 2000 } \\
(\mathbf{n = 7 6})\end{array}$ & $\begin{array}{l}\text { After 2000 } \\
(\mathbf{n = 1 9 3 )}\end{array}$ \\
\hline Termination Provision & 0.146 & 0.702 & $74.3 \%$ & $76.6 \%$ \\
\hline Condemnation Provision & 0.017 & 0.895 & $69.3 \%$ & $70.2 \%$ \\
\hline Acts of God Provision & 11.395 & $\mathbf{0 . 0 0 1}$ & $45.3 \%$ & $67.7 \%$ \\
\hline Amendment Provision & 30.514 & $<\mathbf{0 . 0 0 1}$ & $42.1 \%$ & $77.2 \%$ \\
\hline Dispute Resolution Provision & 4.870 & $\mathbf{0 . 0 2 7}$ & $23.7 \%$ & $37.8 \%$ \\
\hline
\end{tabular}

\subsection{Restrictiveness}

Trends in land-use restrictions differed by land-use. Waste dumping and mining were more

likely to be prohibited after 2000 while other land-use terms showed no significant change

281 (Table 3).

282 Table 3. Percent of CEs with each land-use restriction before and after $2000(n=269)$.

\begin{tabular}{|l|r|r|r|r|}
\hline & \multicolumn{1}{|l|}{$\chi^{2}$} & $\begin{array}{l}\text { P- } \\
\text { value }\end{array}$ & $\begin{array}{l}\text { Before } \\
\mathbf{2 0 0 0} \\
(\mathbf{n = 7 6})\end{array}$ & $\begin{array}{l}\text { After 2000 } \\
(\mathbf{n = 1 9 3})\end{array}$ \\
\hline Alteration of Land Restricted & 0.186 & 0.666 & $77.6 \%$ & $75.1 \%$ \\
\hline Waste Dumping Restricted & 9.301 & $\mathbf{0 . 0 0 2}$ & $81.6 \%$ & $93.8 \%$ \\
\hline Alteration of Water Courses Restricted & 3.167 & 0.075 & $63.2 \%$ & $74.1 \%$ \\
\hline Mining Prohibited & 4.613 & $\mathbf{0 . 0 3 2}$ & $49.3 \%$ & $64.0 \%$ \\
\hline Public Access Allowed & 0.465 & 0.495 & $26.3 \%$ & $22.4 \%$ \\
\hline Commercial Recreation Prohibited & 0.041 & 0.839 & $28.9 \%$ & $30.2 \%$ \\
\hline $\begin{array}{l}\text { Landowner Plantings Restricted or } \\
\text { Landowner Required to Manage } \\
\text { Invasive Species }\end{array}$ & 3.292 & 0.070 & $22.4 \%$ & $33.7 \%$ \\
\hline \hline
\end{tabular}


283 CEs were more likely to allow development after 2000 (Fig. 3a). CEs have become twice as

284 likely to allow one residence or other structures (including agricultural buildings, sheds or

285 cabins) and 2.5 times more likely to allow two or more residences than no development (odds

286 ratios in Table 4).

287 Figure 3. Since 2000, conservation easements have shifted to allowing more development (2a,

$288 \mathrm{n}=269)$, some timber harvesting $(2 \mathrm{~b}$, forested properties $\mathrm{n}=126)$ and some grazing $(2 \mathrm{c}$,

289 grass/shrub properties $\mathrm{n}=108$ ).

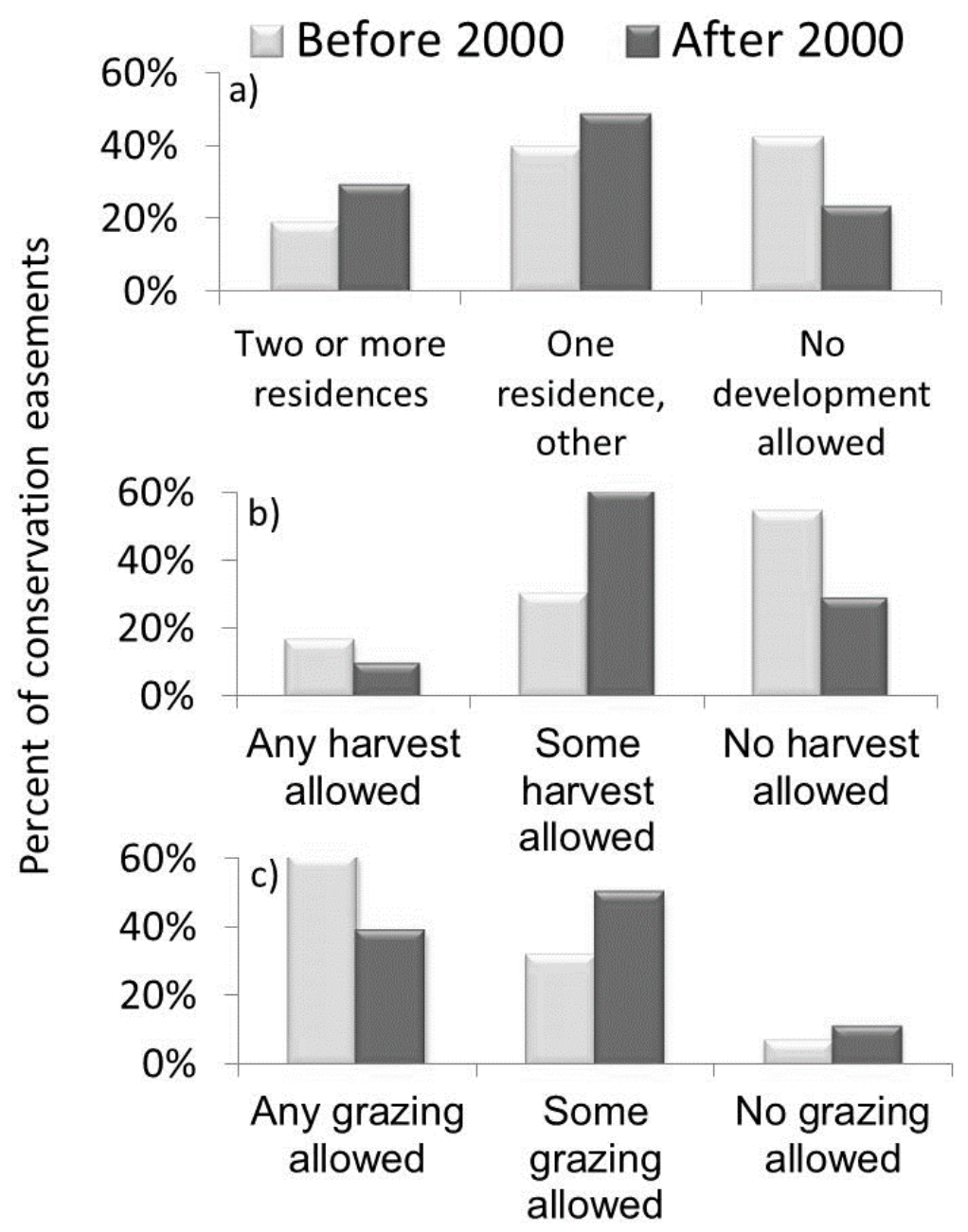

291 Interestingly, half (52\%) of South Carolina's CEs allowed for two or more residences, 
292 compared to only $9 \%$ to $27 \%$ of CEs in each of the other five states.

293 Table 4. Results of a multinomial logistic regression indicating the effects of size, year, and

294 working land purpose on the likelihood of allowing development (reference category is no

295 development allowed).

\begin{tabular}{|c|c|c|c|c|c|c|}
\hline & \multicolumn{3}{|c|}{$2+$ residences vs No development } & \multicolumn{3}{|c|}{$\begin{array}{c}1 \text { residence or other } \\
\text { structures vs No } \\
\text { development }\end{array}$} \\
\hline & B & p-value & $\begin{array}{l}\text { Odds } \\
\text { ratio }\end{array}$ & $\mathrm{B}$ & $\begin{array}{c}\mathrm{p}- \\
\text { value }\end{array}$ & $\begin{array}{l}\text { Odds } \\
\text { ratio }\end{array}$ \\
\hline Year (after 2000) & 0.916 & 0.028 & 2.499 & 0.676 & 0.046 & 1.965 \\
\hline Working land purpose & 1.759 & $<0.001$ & 5.804 & 1.667 & $<0.001$ & 5.294 \\
\hline Property size $(>500 \mathrm{ac})$ & 1.755 & $<0.001$ & 5.786 & 0.87 & 0.016 & 2.388 \\
\hline Intercept & -2.127 & $<0.001$ & & -0.847 & 0.006 & \\
\hline $\mathrm{N}$ & \multicolumn{2}{|r|}{269} & & & & \\
\hline$\chi^{2}$ & \multicolumn{2}{|r|}{68.854} & & & & \\
\hline Df & \multicolumn{2}{|r|}{6} & & & & \\
\hline p-value & \multicolumn{2}{|r|}{$<0.001$} & & & & \\
\hline $\begin{array}{l}\text { Goodness of Fit, } \\
\text { Pearson }\end{array}$ & \multicolumn{2}{|c|}{$\chi^{2}=11.386, \mathrm{df}=8, \mathrm{p}=0.183$} & & & & \\
\hline $\begin{array}{l}\text { Pseudo R-squared, Cox } \\
\text { and Snell }\end{array}$ & \multicolumn{2}{|r|}{0.226} & & & & \\
\hline$\%$ Predicted Correctly & \multicolumn{2}{|r|}{$54 \%$} & & & & \\
\hline
\end{tabular}

297 Timber harvest and grazing terms experienced a shift toward the middle. That is, timber

298 harvests are less likely to be prohibited and more likely to be explicitly permitted with some

299 restrictions in the CE or a management plan after 2000 (Fig. 3b). Before 2000, 54\% of forested

300 CEs did not allow harvest, compared to only $30 \%$ of forested CEs after 2000. CE terms that

301 allowed harvest with some restrictions increased from $30 \%$ of forested CEs before 2000 to $61 \%$

302 after 2000, while terms that allowed any unrestricted harvest or were silent on harvest declined

303 from $16 \%$ before 2000 to $10 \%$ after 2000 . The shift from no harvest to some harvest with

304 restrictions was significant in the multinomial logistic regression that controlled for working land 
305 purpose (Appendix Table 3). The odds ratios indicated that CEs were 3 times more likely to

306 allow some harvest with restrictions than no harvest ( 1 /odds ratio of $0.33=3.03$ ) or any

307 unrestricted harvest (1/odds ratio of $0.31=3.23)$ after 2000.

308 Grazing terms also provided some evidence of a shift to the middle, meaning that fewer 309 properties prohibited grazing outright and fewer properties allowed it without restriction after

3102000 (Fig. 3c). Before 2000, only 32\% of grass/shrub CEs include some restrictions on grazing

311 in the CE or management plan, whereas 50\% of those after 2000 included some restrictions. The

312 percent of CEs with no grazing restrictions declined from $61 \%$ to $39 \%$. No grazing is allowed in

$3137 \%$ of CEs grass/shrub CEs before 2000 and $11 \%$ after 2000. Grazing terms had a marginally-

314 significant shift from any harvest allowed to some harvest allowed with restrictions, once

315 property size and working land purpose were controlled for in the model (Appendix Table 4).

316 3.3. Perceived changes in CE terms

317 Based on inductive coding, we identified recurring themes in response to questions asking

318 whether an organization's approach to drafting CEs had changed, and if so, how and why it

319 changed (Table 5). The majority of interviewees (85\%) stated that the organization had changed

320 its approach to drafting. An additional two interviewees initially stated that the approach had not

321 changed, but then described changes (increasing the percent of interviewees discussing changes

322 to $88 \%$ ). While most described a shift toward complexity, we also heard that some organizations

323 are starting to reign in the complexity of CEs in favor of simple, clear terms. We heard

324 conflicting views about whether recent CEs are more or less restrictive of private land uses. 
Table 5. Interview responses from organization staff describing types of change in conservation

327 easement (CE) drafting $(n=73)$.

\begin{tabular}{|c|c|c|}
\hline $\begin{array}{l}\text { Change to CE } \\
\text { drafting } \\
\text { approach }\end{array}$ & $\begin{array}{l}\text { \# of } \\
\text { interviewees }\end{array}$ & Representative statements or examples from interviews \\
\hline $\begin{array}{l}\text { CEs are more } \\
\text { specific, detailed }\end{array}$ & 27 & $\begin{array}{l}\text { "Much longer and more detailed over time, with much } \\
\text { more professional drafting" }\end{array}$ \\
\hline $\begin{array}{l}\text { Influence of a } \\
\text { particular staff }\end{array}$ & 15 & "Documents changed based on the attorney involved." \\
\hline $\begin{array}{l}\text { Use of model } \\
\text { CE }\end{array}$ & 14 & Organizations developed templates \\
\hline Less restrictive & 12 & $\begin{array}{l}\text { "Whenever possible we get away from micromanagement } \\
\text { type issues on the property, for instance trying to not be } \\
\text { involved in day-to-day management type issues...." }\end{array}$ \\
\hline $\begin{array}{l}\text { Shift in } \\
\text { organization } \\
\text { focus }\end{array}$ & 8 & $\begin{array}{l}\text { The organization was more preservationist focused before, } \\
\text { but now has more "working land easements." }\end{array}$ \\
\hline $\begin{array}{l}\text { Reaction to IRS } \\
\text { or case law }\end{array}$ & 8 & $\begin{array}{l}\text { "Due to IRS ranks becoming stricter, easements must } \\
\text { become more sophisticated and detailed to meet the } \\
\text { regulations." }\end{array}$ \\
\hline $\begin{array}{l}\text { Organization } \\
\text { looked to LTA }\end{array}$ & 7 & $\begin{array}{l}\text { "Basically we've followed the changes in the Land Trust } \\
\text { Alliance's approach to easement drafting." }\end{array}$ \\
\hline $\begin{array}{l}\text { Easier to enforce } \\
\text { or monitor }\end{array}$ & 6 & $\begin{array}{l}\text { "[We] are using more terms that are monitorable and } \\
\text { enforceable and trying to provide flexibility for adaptive } \\
\text { management." }\end{array}$ \\
\hline Less specific & 5 & "The language used to be too specific" \\
\hline Simpler & 4 & Desire to make the language "clearer" and "more simple" \\
\hline $\begin{array}{l}\text { More } \\
\text { prohibitions }\end{array}$ & 4 & $\begin{array}{l}\text { "... much easier to constrain an activity than it is to } \\
\text { prescribe one." Constraints can be documented and } \\
\text { tracked. }\end{array}$ \\
\hline
\end{tabular}

4. DISCUSSION

\subsection{Hypothesis 1: Increasing Complexity}

331 Consistent with our expectations, CEs have become more complex and detailed. Our analysis

332 of CE documents and interviews with conservation practitioners shows how CEs are increasing

333 in complexity. This increase in complexity likely has many sources, including repeat players in 
334 negotiations, contingency planning, diffusion of innovation, organizational learning, and the

335 increased prominence of purchased CEs on large properties with working land uses.

336 4.1.1. Purposes

337 Within our sample, the number and specificity of purposes increased over time. These more

338 diverse purposes may be an effort to ensure compliance with state and federal law as parties

339 mirror the language that appears in statutes. CE purposes may also respond to judicial action. For

340 example, conservationists worry about the implications of the doctrine of changed conditions,

341 which suggests that when circumstances change the landscape such that purposes can no longer

342 be fulfilled, CEs will terminate (Jay, 2012). Adding purposes to a CE could then serve as a

343 backstop: if one purpose becomes impossible to fulfill, the CE need not face termination if

344 another purpose can be met. Some holders may seek to expand the number of purposes because

345 most CEs prohibit any actions inconsistent with the CE's purposes. An expansion of purposes

346 then can serve as a legal hook to later prevent uncontemplated landowner action. Such language

347 has been used to prevent erecting cellphone towers (T-Mobile Northeast v. Town of Islip

348 (2012c)) and filling in sinkholes (The Nature Conservancy v. Sims,(2012a)), and may serve as a

349 way to prohibit hydrofracking (Stockport Mountain Corp. v. Norcross Wildlife

350 Foundation(2012b)).

351 However, an increasing number of purposes could cause trouble for both enforcement and

352 management of protected lands. Most CEs did not identify dominant purposes. Enforcement

353 concerns arise when holders and courts are faced with multiple conflicting mandates without an

354 indication of which might take precedence. Generally, multiple purposes can create confusion for

355 land managers (Fischman, 2002). Purposes may become incompatible, and individual land-use 
356 restrictions and permissions may conflict with one or more purposes.

\section{4.1.2. Land-Use Terms}

358 CEs since 2000 are likely to mention more land-use terms such as for dumping waste,

359 mining, and subdivision of the property. Land-use terms are likely to increase for some of the

360 same reasons as purposes. Increased litigation and scrutiny by the IRS as well as involvement by

361 other government entities like state attorneys general may also lead drafters to add language

362 clarifying rights and responsibilities. Additionally, as CEs cover larger and more varied

363 properties in more circumstances (e.g., in development schemes or in working landscapes), there

364 may be a greater need to explain permitted and prohibited land uses.

365 One of the biggest increases was in management plans, which is an intriguing phenomenon.

366 On one hand it represents an acknowledgement of both the need to accommodate change and the

367 potential need for active land management (Rissman et al., 2014). On the other hand,

368 management plans can provide an avenue for delaying controversial decisions regarding CE

369 terms as items eluding agreement can be pushed off for consideration another day and hidden

370 from public review (Rissman et al., 2013).

371 4.1.3. Procedural Clauses

372 Later CEs were more likely to contain procedural boilerplate clauses regarding Acts of God,

373 dispute resolution, and amendment. Interviews indicated that sometimes these new clauses

374 appeared when new staff members or outside attorneys began drafting the documents. This may

375 have the impact of leaving terms in subsequent CEs with individual staff members no longer

376 certain of their origin (Argote, 1999). The largest increase was in amendment clauses, which is

377 particularly noteworthy as it accompanies a heated debate within the conservation community 
378 about the role of amendments. Some have argued that perpetual agreements should not be

379 amended and this generally appears to be the view of the IRS (Bjork v. Draper (2010)).

380 However, most conservationists acknowledge that it is unrealistic and impractical to have long-

381 term agreements without mechanisms for change. The Land Trust Alliance recommends

382 including amendment clauses and having amendment policies (Alliance, 2004) and accreditation

383 requires it (Commission, 2014). This trend may help explain the increased presence of dispute

384 resolution and Acts of God clauses. We may also be starting to see some backlash or course

385 correction in response to the increasing complexity of CE terms in which organizations are

386 focusing more on designing decision-making processes for settling CE disputes.

\section{4.2. Hypothesis 2: Decreasing Restrictiveness}

388 We hypothesized that land use terms have become less restrictive, but the trends we found 389 are more complex. Restrictions on development have declined, and CEs created after 2000 are

390 twice as likely to allow at least one or two residences than CEs before 2000. However, we found

391 a shift toward compromise for timber harvest and grazing, with a decline in complete

392 prohibitions on timber harvest and a decline in completely unrestricted grazing. Provisions

393 regarding waste dumping and mining tended to be more restrictive. The presence of a mining

394 term may be influenced by federal tax regulations requiring limitations on mining for tax-

395 deductible CEs.

396 The patterns of CE evolution reflect broader trends in conservation policy and philosophy.

397 Earlier CEs were viewed as a close alternative to fee simple ownership in which some

398 landowners desired or were willing to accept limited land uses on their properties. We see

399 evidence of the shift toward conserving used landscapes and the intent to promote compatibility

400 between natural resource production and conservation (Brunson and Huntsinger, 2008; Sayre, 
401 2005). However at some level, increasing private land uses also suggests challenges for

402 preventing undue private benefit and abuse of the CE tool. Meanwhile, increasing knowledge

403 about conservation science indicates conservation benefits may be available in small slices. For

404 example, practitioners may be more confident about allowing selective cutting of a forest parcel

405 and still protecting some species habitat and water quality benefits. This has led to a shift toward

406 the middle as the parties seek to compromise on the private land uses permitted on conserved

407 properties.

408 5. CONCLUSION

409 CEs held a promise of being a simple low-cost alternative to fee-simple acquisition, but are

410 becoming increasingly complex. As CEs get complex we have shown that they have become

411 more restrictive for mining, waste dumping, and grazing, but less restrictive for development and

412 timber harvesting. CEs are more likely to detail what landowners can and cannot do and consider

413 more issues than they had previously. CEs are being used more often and in more contexts.

414 Where CEs cover larger land areas, they are more likely to spell out rights and obligations and

415 related to multiple land uses. We show that the question of what it means to conserve private

416 land, and what balance of private and public rights and responsibilities are being codified in

417 conservation restrictions, has changed over time. In an era of fragmented and devolved

418 governance, nonprofit organizations and governments with considerable rulemaking autonomy

419 are negotiating conservation terms. It is important to understand these choices and trends shaping

420 the private-land conservation estate. 
424

425

426

427

428

429

430

431

432

433

434

435

436

437

438

439

440

441

442

443

444

445

446

447

448

449

450

451

452

453

454

455

456

457

458

459

460

461

462

463

464

465

466

467

2010. Bjork v. Draper, N.E.2d. Appellate Court of Illinois, Second District, p. 763.

2012a. The Nature Conservancy v. Sims, Federal 3d. United States Court of Appeals, Sixth Circuit, p. 672.

2012b. Stockport Mountain Corp. v. Norcross Wildlife Foundation, Not Reported. United States District Court, Middle District Pennsylvania, p. 719345.

2012c. T-Mobile Northest LLC v. Town of Islip. United States District Court, Eastern District of New York, p. 338.

Alliance, L.T., 2004. Land Trust Standards and Practices. 24.

Alliance, L.T., 2013. LTA Timeline.

Argote, L., 1999. Organizational learning : creating, retaining, and transferring knowledge.

Boston, Kluwer Academic.

Argote, L., 2013. Organization Learning: A Theoretical Framework, Organizational Learning.

Springer US, pp. 31-56.

Argyres, N.S., Bercovitz, J., Mayer, K.J., 2007. Complementarity and Evolution of Contractual

Provisions: An Empirical Study of IT Services Contracts. Organization Science 18, 3-19.

Asch, S.E., 1955. Opinions and Social Pressure, In: Aronson, E. (Ed.), Readings about The Social Animal, 9th ed. Worth Publishers, New York, NY, pp. 17-26.

Boyatzis, R.E., 1998. Transforming Qualitative Information: Thematic Analysis and Code

Development. Sage, Thousand Oaks, CA.

Boyd, J., Caballero, K., Simpson, R.D., 1999. The Law and Economics of Habitat Conservation:

Lessons from an Analysis of Easement Acquisitions. Resources for the Future, Washington D.C., pp. 1-42.

Brunson, M.W., Huntsinger, L., 2008. Ranching as a conservation strategy: can old ranchers save the new West? Rangeland Ecol. Manage. 61, 137-147.

Chang, K., 2011. 2010 National Land Trust Census Report, In: Alliance, L.T. (Ed.). Land Trust Alliance, Washington D.C.

Cheever, F., 1996. Public Good and Private Magic in the Law of Land Trusts and Conservation Easements: A Happy Present and a Troubled Future. Denver University Law Review, 10771102.

Colman, A.M., 2012. Oxford Dictionary of Psychology, 3d ed. Oxford University Press, Oxford. Commission, L.T.A., 2014. Accreditation Requirements Manual. 90.

Crocker, K.J., Reynolds, K.J., 1993. The Efficiency of Incomplete Contracts: An Empirical Analysis of Air Force Engine Procurement. The RAND Journal of Economics 24, 126-146. Di Leva, C.E., 2002. The Conservation of Nature and Natural Resources through Legal and Market-Based Instruments. Review of European Community \& International Environmental Law 11, 84-95.

Fischman, R.L., 2002. The National Wildlife Refuge System and the hallmarks of modern organic legislation. Ecology Law Quarterly 29, 457-622.

Gray, V., 1973. Innovation in the States: A Diffusion Study. The American Political Science Review 67, 1174-1185.

Haines, J., 2012. Kayln M. Carpenter v. Commissioner of Internal Revenue US Tax Court. Jacobs, H.M., 2014. Conservation Easements in the U.S. and Abroad: Reflections and Views Toward the Future, Lincoln Institute of Land Policy Working Paper. Lincoln Institute of Land Policy, Cambridge, MA, p. 18. 
Jay, J.E., 2012. When Perpetual is Not Forever: The Challenge of Changing Conditions, Amendment, and Termination of Perpetual Conservation Easements

Harvard Environmental Law Review 36, 1-78.

Korngold, G., 2010. Globalizing Conservation Easements: Private Law Approaches for International Environmental Protection. Wisconsin International Law Journal 28, 585-638. Mayer, K.J., Argyres, N.S., 2004. Learning to Contract: Evidence from the Personal Computer Industry. Organization Science 15, 394-410.

McLaughlin, N.A., 2004. Increasing the tax incentives for conservation easement donations - A responsible approach. Ecology Law Quarterly 31, 1-115.

Merenlender, A.M., Huntsinger, L., Guthey, G., Fairfax, S.K., 2004. Land Trusts and Conservation Easements: Who Is Conserving What for Whom?

Patronatos Agrarios y Servicios de Conservación: ¿Quién Está Conservando Qué para Quién?

Conservation Biology 18, 65-76.

NCCUSL, N.C.o.C.o.U.S.L., 2007. Uniform Conservation Easement Act. Uniform Law

Commission.

Owley, J., 2006. The Emergence of Exacted Conservation Easements. Nebraska Law Review, 1043-1112.

Owley, J., 2011. The Enforceability of Exacted Conservation Easements. Vermont Law Review $36,261-302$.

Owley, J., 2013. From Citizen Suits to Conservation Easements: The Increasing Private Role in Public Permit Enforcement. Environmental Law Reporter News and Analysis 43, 10486-10491. Rissman, A.R., 2010. Designing Perpetual Conservation Agreements for Land Management. Rangeland Ecology \& Management 63, 167-175.

Rissman, A.R., 2011. Evaluating conservation effectiveness and adaptation in dynamic landscapes, Law and Contemporary Problems, p. 145+.

Rissman, A.R., Cheever, F., Owley, J., Shaw, R., Thompson, B.H., Weeks, W.W., 2013. Private land conservation and climate change: rethinking strategies and tools. A report to the land conservation community. Woods Institute for the Environment, Stanford University, Palo Alto, CA.

Rissman, A.R., Owley, J., Shaw, M.R., Thompson, B., 2014. Adapting conservation easements to climate change. Conservation Letters, n/a-n/a.

Root-Bernstein, M., Montecinos Carvajal, Y., Ladle, R., Jepson, P., Jaksic, F., 2013.

Conservation easements and mining: The case of Chile. Earth's Future 1, 33-38.

Sayre, N.F., 2005. Working wilderness: the Malpai Borderlands Group and the future of the western range. Rio Nuevo Publishers, Tucson, AZ.

Stolton, S., Redford, K.H., Dudley, N., 2014. The Futures of Privately Protected Areas: Developing Capacity for a Protected Planet, In: IUCN (Ed.), Protected Area Technical Report. IUCN, Switzerland.

Tegene, A., Wiebe, K., Kuhn, B., 1999. Irreversible Investment Under Uncertainty: Conservation Easements and the Option to Develop Agricultural Land. Journal of Agricultural Economics 50, 203-219.

Telesetsky, A., 2001. Graun Bilong Mipela Na Mipela No Tromweim: The Viability of International Conservation Easements to Protect Papua New Guinea's Declining Biodiversity. Georgetown International Environmental Law Review 13, 735-780.

Vanneste, B.S., Puranam, P., 2008. Repeated Interactions and Contractual Detail: Identifying the Learning Effect. Organization Science 21, 186-201. 
514

515 